Rapid Reviews COVID-19

\title{
Reviews: "College \\ Openings, Mobility, and the \\ Incidence of COVID-19 \\ Cases"
}

Noemi Kreif ${ }^{1}$

${ }^{1}$ University of York

Published on: Mar 03, 2022

License: Creative Commons Attribution 4.0 International License (CC-BY 4.0). 
To read the original manuscript, click the link above.

Reviewer 1 (Noemi K...) |

RR:C19 Strength of Evidence Scale Key.

$$
\begin{aligned}
& \text { प्रमप् = Misleading } \\
& \text { प्र प्र० = Not Informative }
\end{aligned}
$$

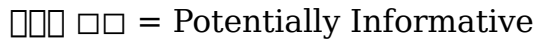

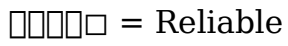

$$
\begin{aligned}
& \text { प्राप्र }=\text { Strong }
\end{aligned}
$$

To read the reviews, click the links below. 